\author{
Safi Nur Indahsari \& Ratri Wulandari \\ Universitas Telkom \\ safisafi33750@gmail.com \\ ratriwulandari@telkomuniversity.ac.id
}

\title{
ANALISIS ERGONOMI LINGKUNGAN RUANG TUNGGU SELATAN STASIUN BANDUNG BERDASARKAN STANDAR KENYAMANAN PENGGUNA
}

\begin{abstract}
:
Train station waiting area is an area to wait for departure that should accomodate every user. Waiting area at Bandung Train Station is located on the north and south gate. Study on environmental ergonomics at Bandung Station waiting area was done to find out the level of user comfort, aiming to know the advantages and disadvantages of Bandung Station waiting area related to comfort aspect that had been fullfilled and unfullfilled. The area of study is waiting area on the South gate of Bandung Station.

The comfort level of waiting area at Bandung Station was studied through environmental ergonomics study that composed of anthropometry, circulation, temperature, air circulation, lighting, noise, vibration, smells using Android application as measurement tool. As a supplement, a review on sitting facility at Bandung Station was also done.

This research is a qualitatie descriptive research with observation and measurement methods. It focused on records that describe actual field situation to support data presentation.

From the research it is concluded that waiting area at South Bandung Station has fullfilled environmental ergonomic aspects in various elements except lighting and passenger circulation.
\end{abstract}

Keywords: Lounges, Environmental Ergonomics, Railway Station

\begin{abstract}
Abstrak:
Ruang tunggu stasiun kereta api adalah ruang tempat menunggu keberangkatan penumpang yang harus mengakomodasi semua pengguna. Ruang tunggu pada Stasiun Bandung terdapat pada pintu Utara dan Selatan. Kajian tentang ergonomi lingkungan ruang tunggu Stasiun Bandung dilakukan untuk mengetahui tingkat kenyamanan pengguna, dengan tujuan mengetahui kelebihan dan kekurangan ruang tunggu Stasiun Bandung dalam hal aspek kenyamanan yang telah terpenuhi dan belum terpenuhi. Area yang menjadi objek penelitian adalah ruang tunggu pada pintu Selatan Stasiun Bandung.

Tingkat kenyamanan ruang tunggu pada Stasiun Bandung dikaji melalui kajian ergonomi yang mencakup antropometri, sirkulasi, temperatur, sirkulasi udara, pencahayaan, tingkat kebisingan, getaran mekanik, bau-bauan dengan menggunakan alat pengukur aplikasi Android. Sebagai pelengkap dilakukan juga tinjauan fasilitas kursi duduk Stasiun Bandung.

Penelitian ini merupakan penelitian deskriptif kualitatif dengan metoda observasi dan pengukuran. Penelitian menekankan pada catatan yang menggambarkan situasi sebenarnya di lapangan guna mendukung penyajian data. Dari hasil penelitian, dapat disimpulkan bahwa ruang tunggu Stasiun Selatan Bandung telah memenuhi aspek standar ergonomi lingkungan dalam beberapa hal kecuali pencahayaan dan sirkulasi pengunjung.
\end{abstract}

Kata Kunci:Ruang tunggu, Ergonomi Lingkungan, Stasiun Kereta Api

\section{Pendahuluan}

Di kota besar, transportasi publik merupakan salah satu unsur penting yang harus ada untuk mendukung mobilitas penduduk. Salah satu transportasi publik yang diminati masyarakat adalah kereta api. Hal ini dikarenakan kereta mempunyai banyak kemudahan dan keuntunggan bila dibandingkan dengan transportasi lainnya, seperti jalur tanpa hambatan dan waktu keberangkatan yang relatf lebih cepat. Tingginya minat masyarakat kepada angkutan publik ini sebaiknya dibarengi dengan peningkatan sarana dan prasarana stasiun kereta itu sendiri. 
Sarana prasarana stasiun kereta api mencakup banyak hal, seperti fasilitas-fasilitas standar pelayanan seperti sarana informasi, loket penjualan tiket, toilet, ruang ibadah, dan fasilitas yang tidak kalah penting dan sangat mempengaruhi aspek kenyamanan sebuah stasiun adalah fasilitas ruang tunggu.

Stasiun Kereta Api Bandung pintu selatan memiliki fasilitas ruang tunggu yang berada pada area utama. Hal ini membuat pengunjung tidak kesulitan dalam menemukan ruang tunggu karena keadaan eksisting yang menguntungkan yaitu berada pada satu area tunggal. Akan tetapi keadaan ruang tunggu yang mempunyai penataan yang kurang jelas sirkulasi yang bercampur dengan sirkulasi keberangkatan, tidak adanya pembagian area yang jelas serta kurangnya fasilitas kursi duduk pada ruang tunggu membuat ruang tunggu tampak tidak terkoordinasi dengan baik dan pengunjung cenderung kurang merasakan kenyamanan pada ruang tunggu.

Objek penelitian ini adalah ruang tunggu luar Stasiun Bandung yang terletak di pintu selatan. Dengan menggunakan metode deskripsi kualitatif. Penelitian menekankan pada catatan yang menggambarkan situasi sebenarnya di lapangan guna mendukung penyajian data. Langkahlangkah yang dilakukan dalam penelitian ini, mencakup survey dan observasi lapangan yaitu Stasiun Bandung dilanjutkan dengan studi literatur baik dari buku, jurnal, maupun internet sebagai dasar analisis, serta wawancara dengan pengunjung Stasiun Bandung. Untuk mendukung literatur yang ada, dilakukan kuesioner singkat sebagai tambahan sumber data. Selanjutnya data yang didapat dianalisis sesuai dengan literatur yang dijadikan pedoman penelitian, sehingga penelitian ini diharapkan mampu memecahkan permasalahan terkait kenyamanan ruang tunggu selatan pada Stasiun Bandung.

Permasalahan yang menjadi fokus dalam penelitian ini adalah besaran tingkat kenyamanan ruang tunggu selatan Stasiun Bandung yang ditinjau dari ergonomi lingkungan

\subsection{Stasiun Kereta Api Bandung}

Berdasarkan informasi dari berbagai sumber, diantaranya buku Ngalingkung Bandung terbitan Pikiran Rakyat (2016), situs Stasiun Bandung dan web Komunitas Aleut, Stasiun Bandung merupakan stasiun utama kereta api di Kota Bandung, berlokasi di Jalan Stasiun Timur No. 1 untuk pintu selatan dan Jalan Kebon Kawung No. 43 (pintu utara). Stasiun Bandung diresmikan tanggal 17 Mei 1884, digunakan untuk mengangkut hasil produksi perkebunan seperti kina, teh, kopi, karet dari Bandung ke Batavia melalui Bogor dan Cianjur. Bangunanstasiun mengalami beberapa kali perombakan. Pada tahun 1909, bangunan stasiun mengalami perluasan dan perombakan desain oleh arsitek FJA Cousin. Salah satu perubahan tersebut ditandai dengan hiasan kaca patri pada peron bagian selatan yang bergaya Art Deco.

Desain terakhir merupakan karya arsitek E.H. de Roo pada tahun 1928.

Stasiun Bandung melayani transportasi jarak pendek dan antar provinsi. Stasiun Bandung terdiri dari satu lantai dengan dua pintu utama, yaitu pintu utara dan pintu selatan. Dimana pintu Utara adalah pintu utama yang lebih besar dengan akses fasilitas berupa cafeteria, ATM, Minimarket, Retail, Musholla, Informasi center dan juga ruang tunggu. Sedangkan pintu selatan terdapat fasilititas ATM, kantor, minimarket, loket tiket dan ruang tunggu. 


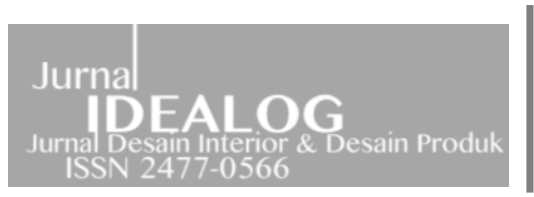

Berdasarkan Peraturan Menteri Perhubungan no. 33 tahun 2011, Peraturan Pemerintah Republik Indonesia Nomor 56 Tahun 2009 Tentang Penyelenggaraan Perkeretaapian, UndangUndang Republik Indonesia Nomor 23 Tahun 2007 Tentang Perkeretaapian

Stasiun Bandung termasuk ke dalam kategori stasiun penumpang kelas besar. Hal ini diperkuat dengan pernyataan PT KAI dalam laporan tahunan tahun 2012 bahwa Stasiun Bandung merupakan stasiun penumpang kelas besar.

\subsection{Ruang Tunggu Selatan Stasiun Kereta Api Bandung}

Fokus penelitian ini adalah ruang tunggu selatan Stasiun Bandung. Ruang tunggu terletak didepan pintu masuk dan berada di tengah ruangan yang berdampingan dengan jalur sirkulasi menuju peron. Pada sekitar ruang tunggu terdapat minimarket, loket tiket, kantor dan stand informasi.

\section{Metoda}

Penelitian ini menggunakan metoda deskripsi kualitatif. Penelitian ini menekankan pada catatan yang menggambarkan situasi sebenarnya di apangan guna mendukung penyajian data. Langkah-langkah yang dilakukan dalam penelitian ini, antara lain:

- Studi Literatur: studi standar kenyamanan dan fasilitas yang ditinjau dari literatur, baik dari buku maupun internet sebagai dasar analisis.

- Survey dan observasi: survey dan observasi lapangan yaitu Stasiun Bandung pintu selatan, khususnya kenyamanan ruang tunggu selatan Stasiun Bandung yang ditinjau dari aspek-aspek ergonomi lingkungan seperti sirkulasi, temperatur, kelembaban, pencahayaan dan lain sebagainya. Dan melakukan survey serta observasi terhadap ruang tunggu utara Stasiun Bandung sebagai data pebanding.

- Dokumentasi: dilakukan pada ruang tunggu utara Stasiun Bandung yang berkaitan dengan segala aspek fasilitas dan kenyamanan.

\section{Kajian Literatur}

Menurut Peraturan Menteri Perhubungan Republik Indonesia No 48 Tahun 2015, ruang tunggu adalah ruangan atau tempat yang disediakan untuk penumpang dan calon penumpang sebelum melakukan check in dengan standar area untuk satu orang minimum $0,6 \mathrm{~m} 2$. Area bersih $100 \%$ terawat dan tidak berbau.

Hakim (2006) menyebutkan bahwa faktor penentu kenyamanan dalam aspek ergonomi berdasarkan kondisi lingkungan mencakup antropometri, sirkulasi, temperatur, sirkulasi udara, pencahayaan, tingkat kebisingan, getaran mekanik, dan bau-bauan.

Disebutkan juga oleh Hakim (2006) bahwa kenyamanan dapat berkurang karena sirkulasi yang kurang baik, seperti tidak adanya pembagian ruang yang jelas untuk sirkulasi manusia, atau tidak ada pembagian sirkulasi antara ruang satu dengan lainnya. Dari kebutuhan dan kegiatan yang terdapat di ruang tunggu maka yang perlu diperhatikan adalah tentang ketidaknyamanan sirkulasi akibat keterbatasan ruang gerak, kurangnya rasa aman akibat keterbatasan ruang, sehingga ruang tunggu harus memiliki akses analisis ergonomi sirkulasi horizontal. Analisis dimensi ergonomi harus didasarkan pada antropometri pengguna normal dan penderita cacat (Panero J dan Zelnik, 2003). 


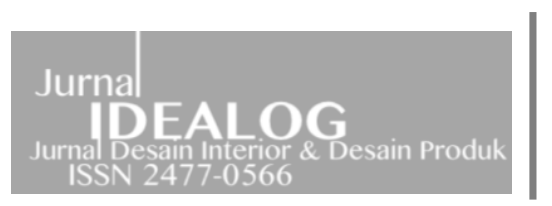

Perhitungan kebutuhan besaran ruang bagi pengguna dengan barang bawaan mencapai standar dimensi radius $91,4 \mathrm{~cm}$. Jarak standar sirkulasi pada area publik satu orang adalah $61 \mathrm{~cm}$ (Panero J dan Zelnik, 2003).

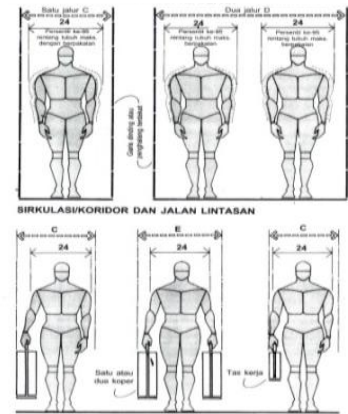

Gambar 1. Jarak bersih rentang tubuh dengan barang bawaan.

Sumber: Panero J dan Zelnik 2003:207

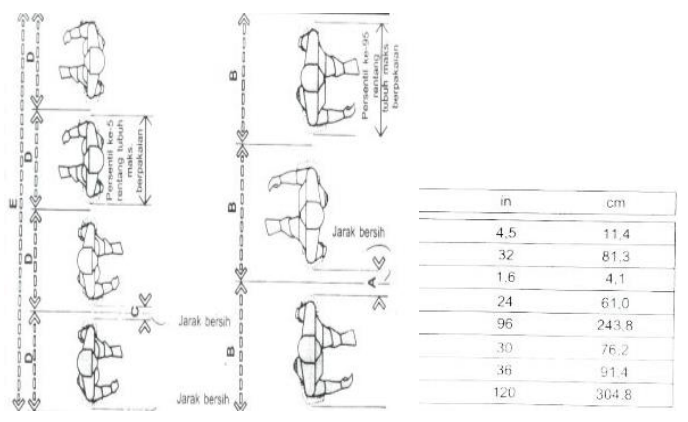

Gambar 2.Jarak bersih sirkulasi horizontal pada koridor.

Sumber: Panero J dan Zelnik 2003:271

Perhitungan kebutuhan besaran ruang bagi pengguna kursi roda, penyandang cacat atau buta yang menggunakan tongkat. Standar dimensi radius per orang pengguna kursi roda adalah 91,4 $\mathrm{cm}$. Zona pergerakan jarak bersih tubuh (diameter) pengguna kursi roda yaitu 137,2 $\mathrm{cm}$ (Penero J dan Zelnik, 2003).

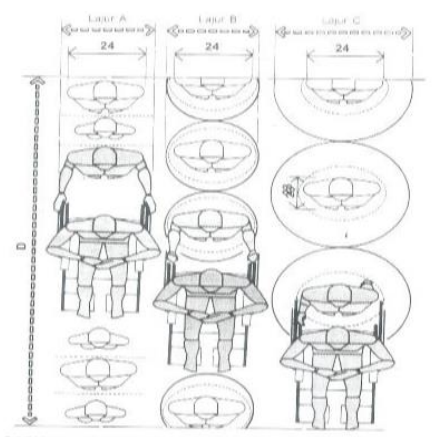

Gambar 3. Zona ruang pergerakan jarak bersih rentang tubuh minimal

Sumber:Penero J dan Zelnik 2003:272

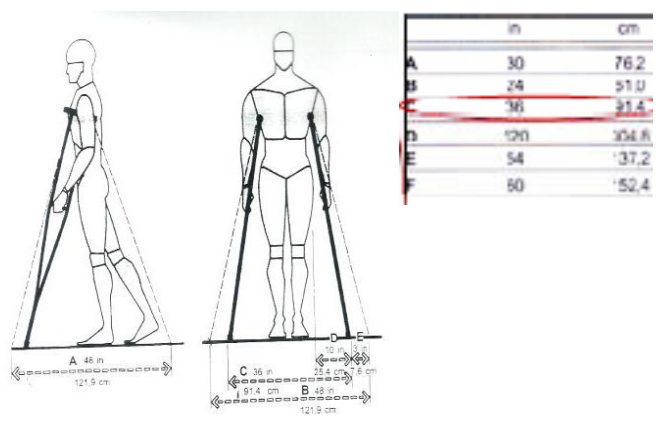

Gambar 4. Zona ruang pergerakan jarak bersih penderita cacat Sumber:Penero J dan Zelnik 2003:48

Terkait temperatur, Hakim (2006) menuliskan kaitan antara temperatur dengan respon kulit manusia. Dalam tulisan tersebut, Hakim (2006) menyebutkan bahwa jika temperatur ruang sangat rendah maka temperatur permukaan kulit akan menurun dan sebaliknya, jika temperatur dalam ruang tinggi, maka temperatur permukaan kulit akan mengalami kenaikan pula. Pengaruh bagi aktivitas adalah bahwa temperatur yang terlalu dingin akan menurunkan gairah dalam beraktivitas dan temperatur yang terlampau panas dapat membuat kelelahan dan ketidaknyamanan (Hakim, 2006). Menurut Depkes suhu tubuh normal manusia adalah $36^{\circ} \mathrm{C}$ $37,5^{\circ} \mathrm{C}$, dan menurut WHO suhu normal $: 37,2^{\circ} \mathrm{C}-37,5^{\circ} \mathrm{C} / 99^{\circ} \mathrm{C}-99,5^{\circ} \mathrm{C}$. Menurut Talarosha (2005), ambang temperatur kenyamanan ruang terbagi menjadi sebagai berikut:

Tabel 1. Suhu Nyaman dan Ambang Atas menurut Standar Tata Cara Perencanaan Teknis Konservasi Energi pada Bangunan Gedung

\begin{tabular}{|l|l|l|}
\hline No. & Kondisi Nyaman & Temperatur Ruang \\
\hline 1 & Sejuk nyaman & $20,5^{\circ} \mathrm{C}-22,8^{\circ} \mathrm{C}$ \\
\hline
\end{tabular}




\begin{tabular}{|l|l|l|}
\hline 2 & Ambang atas sejuk nyaman & $24^{\circ} \mathrm{C}$ \\
\hline 3 & Hangat nyaman & $27,1^{\circ} \mathrm{C}$ \\
\hline 4 & Ambang atas hangat nyaman & $31^{\circ} \mathrm{C}$ \\
\hline
\end{tabular}

Sumber: Talarosha 2005:150

Terkait standar pencahayaan, menurut Peraturan Menteri Perhubungan No 48 tahun 2015, lampu penerangan untuk stasiun besar sebagai sumber cahaya untuk memberikan rasa aman intensitas cahaya 200-250 lux. Titik lampu disesuaikan dengan kebutuhan. Menurut Santosa (2006), pencahayaan di dalam ruang yang baik adalah pencahayaan yang memungkinkan orang yang menempati ruangan tersebut dapat melihat benda-benda dengan jelas. Santosa (2006) juga menyampaikan bahwa tanpa dapat melihat benda-benda dengan jelas maka aktivitas akan terganggu, sebaliknya, cahaya yang terlalu terang juga dapat mengganggu penglihatan.

Penerangan pada tempat umum yang baik adalah penerangan yang memungkinkan orang melihat obyek dengan mudah, jelas dan tanpa upaya yang berlebihan dari indera penglihatannya sehingga aktivitas tidak terganggu.Kriteria Pencahayaan buatan dalam area publik adalah penyebaran sinar merata, temperatur pencahayaan rendah. Lampu yang paling sesuai adalah fluorescent (lampu TL), karena tahan lama dan berbentuk tabung yang membuat cahaya lebih merata dan tidak ada titik yang menyilaukan.

Faktor lain dari kenyamanan terkait dengan tingkat kebisingan. Pada area publik kebisingan adalah salah satu masalah pokok yang bisa mengganggu kenyamanan (Hakim, 2006). Suma'mur (1996) dalam bukunya menyebutkan bahwa pengaruh utama bising terhadap kesehatan berupa kerusakan pada indera pendengaran yang dikenal sebagai dampak auditorial. Terdapat juga dampak lain yang bersifat non auditorial, misalnya, mengganggu komunikasi, gangguan fisiologis seperti sakit kepala, mual dan berdebar. Kualitas suatu bunyi yang bisa menentukan tingkat gangguan terhadap manusia ditentukan oleh tiga aspek, yaitu lama, intensitas dan frekuensinya (Suma'mur, 1996). Berdasarkan Keputusan Menteri Kesehatan No 14/05 tahun 2002 tentang Lingkungan Kerja dan Keputusan Menteri Lingkungan Hidup No 48 tahun 1996 tentang Baku Tingkat Kebisingan, NAB untuk tingkat kebisingan maksimal 85 dBA.

Perihal penghawaan udara diatur dalam Peraturan Menteri Perhubungan No 48 tahun 2015, bahwa pada ruang tunggu stasiun sirkulasi dapat berupa AC, kipas angin, dan atau dari ventilasi udara, suhu dalam ruangan maksimal $27^{\circ} \mathrm{C}$. Sirkulasi udara akan menggantikan udara kotor dengan udara yang bersih. Menurut Laela (2015) sirkulasi dengan sistem ventilasi atau penghawaan alami yang baik, arah dan kecepatan gerak udara, laju udara yang terjadi pada suatu ruang dapat diusahakan untuk menghasilkan kenyamanan dalam ruang tersebut. Luas bukaan udara harus memenuhi syarat untuk mendukung kelancaran sirkulasi udara demi kenyamanan. Kondisi langit-langit yang tinggi akan membuat pertukaran udara semakin baik, karena udara panas tidak sampai ke dasar sehingga tidak akan mempengaruhi kenyamanan ruang. Ventilasi yang baik adalah ventilasi silang (cross ventilation).

Salah satu faktor yang berpengaruh terhadap kenyamanan adalah aroma atau bau-bauan baik itu bersumber dari ruang dalam maupun dari ruang luar. Hal tersebut dapat diatasi dengan memindahkan sumber bau dan menempatkan sumber bau pada area yang tertutup dari pandangan visual (Hakim, 2006).

Faktor lain terkait dengan kenyamanan ruang adalah getaran mekanis. Hakim (2006) menyampaikan bahwa getaran mekanis dapat diartikan sebagai getaran yang ditimbulkan oleh 


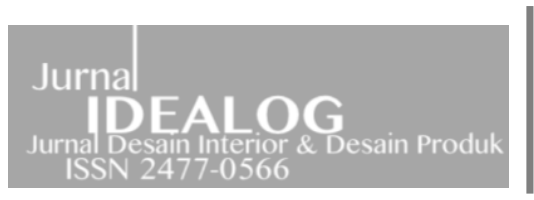

alat-alat mekanis yang sebagian darinya sampai ke tubuh kita dan menimbulkan akibat-akibat yang tidak diinginkan.Secara umum, getaran mekanis dapat mengganggu tubuh dalam hal konsentrasi dan mempercepat timbulnya kelelahan (Hakim, 2006).

Dalam hal kepadatan ruang, terutama untuk ruang tunggu publik, Panero J. dan Zelnik (2003) menganjurkan zona ruang tempat duduk dengan kepadatan tingi mencapai $61 \mathrm{~cm}$, dengan tinggi kursi mencapai $40 \mathrm{~cm}$.
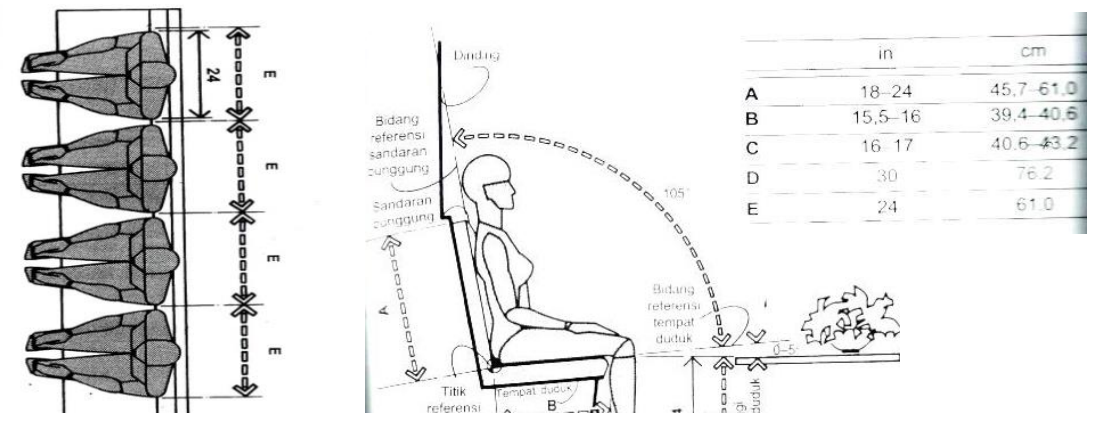

Gambar 5.Zona ruang tempat duduk bangket dengan kepadatan tinggi.

Sumber:Panero J dan Zelnik 2003:129

\section{Hasil dan Diskusi}

\subsection{Sirkulasi}

Dari data dan pengamatan di lapangan, kedekatan atau ruang gerak kursi tunggu satu dan yang lainnya mempunyai jarak rata-rata $60 \mathrm{~cm}$ (pada bagian A). Hal ini sesuai dengan zona gerak minimal perorangan. Akan tetapi, mengingat keadaan stasiun sebagai area publik, maka pengguna memiliki kecenderungan membawa barang bawaan. Standar zona gerak barang bawaan adalah 91,4 cm. Dengan mempertimbangkan fungsi publik dan pengguna yang bersifat universal, maka perlu diperhatikan juga gerak zona difabel. Jarak zona gerak diffable dan penderita cacat (pengguna tongkat) adalah minimal 91,4 cm. Dengan membandingkan jarak aktual lapangan dengan standar minimum pengguna diffable dan pengguna normal dengan barang bawaaan, maka dapat dikatakan bahwa jarak sirkulasi pada zona A tidak sesuai dengan kebutuhan pengguna dengan barang bawaan dan penyandang cacat sekaligus. Kedua pengguna ini harus melewati area sirkulasi secara bergantian. Hal ini tentunya akan menimbulkan ketidaknyamanan pada ruang tunggu.

Pada zona B terdapat kursi tunggu yang berhadapan dengan jarak $70 \mathrm{~cm}$. Berdasarkan teori dan standar minimum sirkulasi, kursi yang berhadapan mempunyai dua sirkulasi dan dua zona gerak perorangan, sehingga minimal jarak sirkulasi adalah $120 \mathrm{~cm}$. Dengan jarak yang begitu dekat, pengguna yang tidak saling mengenal dihadapkan satu sama lain. Ketidaknyamanan akan timbul ketika dua orang berselisih di area sirkulasi tersebut. Selain itu, komunikasi dan konsentrasi akan terganggu karena kurangnya tingkat privasi akibat sempitnya area sirkulasi.

Pada zona $\mathrm{C}$ adalah sirkulasi penggunjung yang menuju area tunggu dalam. Area sirkulasi ini mempunyai jarak $90 \mathrm{~cm}$, dibatasi secara langsung dengan kursi tunggu yang saling membelakangi. Kedekatan serta tidak adanya jarak dari jalur sirkulasi dan kursi tunggu tentu mengganggu pengguna karena tidak adanya pembagian area yang jelas. Jarak $90 \mathrm{~cm}$ telah 


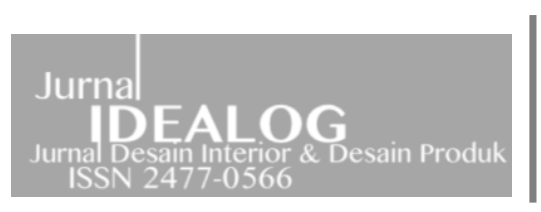

memenuhi jarak minimal zona gerak perorangan, dengan persyaratan bahwa pengguna berjalan secara berurutan. Hal ini tepat untuk mengatasi pemeriksaan tiket oleh petugas. Tetapi tidak adanya jarak pemisah dengan kursi tunggu akan mengganggu pengguna baik yang sedang duduk atau berjalan. Area petugas tiket yang tidak ada jarak dengan kursi tunggu tentu akan mengganggu aktivitas baik petugas maupun pengunjung.

Berdasarkan data dan pengamatan diatas, dapat dikatakan bahwa sirkulasi ruang tunggu dikategorikan tidak nyaman dan belum memenuhi standar kebutuhan, khususnya untuk diffable karena posisi ruang tunggu yang langsung berhadapan dengan sirkulasi menuju area dalam, zona gerak yang tidak sesuai dengan kebutuhan, serta pengaturan layout furnitur yang mengganggu sirkulasi.

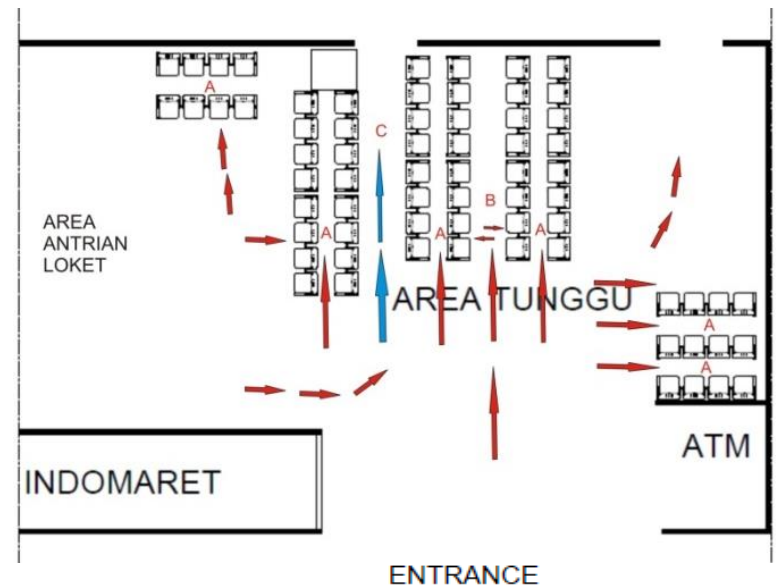

Tabel 2. Jarak sirkulasi ruang tunggu Stasiun Bandung

\begin{tabular}{l|l}
\hline Keterangan & Jarak \\
\hline $\mathrm{A}$ & $60 \mathrm{~cm}$ \\
$\mathrm{~B}$ & $70 \mathrm{~cm}$ \\
$\mathrm{C}$ & $90 \mathrm{~cm}$ \\
\hline \multicolumn{2}{l}{ Sumber: Data pribadi 2015}
\end{tabular}

Keterangan:

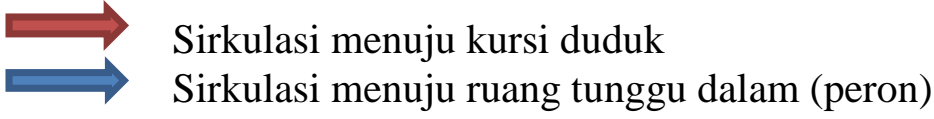

Gambar 6. Sirkulasi ruang tunggu Stasiun Bandung

Sumber: Data pribadi 2015

\subsection{Temperatur}

Dari hasil pengukuran lapangan, data temperatur ruang diperoleh dengan bantuan dua aplikasi android yaitu Smart Thermometer dan Thermometer Free. Data yang diperoleh adalah sebagai berikut:

Tabel 3. Analisis Kenyamanan Temperatur Ruang Tunggu Stasiun Bandung

\begin{tabular}{|c|c|c|c|c|c|}
\hline $\begin{array}{l}\mathrm{N} \\
\mathrm{O}\end{array}$ & Aplikasi & $\begin{array}{l}\text { Temperatur } \\
\text { Ruang }\end{array}$ & $\begin{array}{l}\text { Temperatur } \\
\text { Luar }\end{array}$ & Literatur & Analisis \\
\hline 1 & $\begin{array}{l}\text { Smart } \\
\text { Thermometer }\end{array}$ & $28^{\circ} \mathrm{C}$ & $31^{\circ} \mathrm{C}$ & \multirow{2}{*}{$\begin{array}{l}\text {-Ambang } \\
\text { atas sejuk } \\
\text { nyaman } \\
\text { adalah } \\
24^{\circ} \mathrm{C} \\
\text {-Ambang } \\
\text { atas } \\
\text { hangat } \\
\text { nyaman }\end{array}$} & \multirow{2}{*}{$\begin{array}{l}\text {-Suhu ruang berada pada } \\
\text { rentang kategori hangat } \\
\text { nyaman. } \\
\text {-Perbedaan suhu luar dan } \\
\text { dalam signifikan. } \\
\text {-Perbedaan suhu luar dan } \\
\text { dalam diakibatkan oleh } \\
\text { beberapa faktor yaitu adanya } \\
\text { tanaman yang dapat }\end{array}$} \\
\hline 2 & $\begin{array}{l}\text { Free } \\
\text { Thermometer }\end{array}$ & $28^{\circ} \mathrm{C}$ & $31^{\circ} \mathrm{C}$ & & \\
\hline
\end{tabular}




\begin{tabular}{|l|l|l|l|}
\hline & & $\begin{array}{l}\text { adalah } \\
31^{\circ} \mathrm{C}\end{array}$ & $\begin{array}{l}\text { meredam panas, ventilasi } \\
\text { yang baik serta bentuk } \\
\text { bangunan yang tinggi yang } \\
\text { berakibat pada terciptanya } \\
\text { kenyamanan ruang tunggu. } \\
\text { Desain ruang tunggu } \\
\text { dianggap berhasil dalam hal } \\
\text { kenyamanan temperatur. }\end{array}$ \\
\hline
\end{tabular}

Sumber: Data pribadi 2015.

Data diatas menunjukan bahwa suhu lingkungan ruang tunggu Stasiun Bandung normal atau sesuai dengan kebutuhan dan kenyamanan dalam beraktivitas dengan rata-rata berkisar $28^{\circ} \mathrm{C}$. Tidak ada perubahan temperatur yang mencapai $20 \%$ untuk kondisi panas dan lebih dari 35\% untuk udara dingin. Temperatur pada ruang luar relatif panas dengan suhu rata-rata mencapai $31^{\circ} \mathrm{C}$. Tingginya suhu udara ruang luar dikarenakan faktor seperti polusi udara, panas kendaraan, dan lain-lain. Sedangkan faktor terciptanya temperatur ruang tunggu yang ideal didapat dari beberapa faktor, antara lain ketinggian langit-langit Stasiun Bandung yang mencapai $+709 \mathrm{~cm}$, luasan bukaan besar, sehingga sirkulasi udara berjalan dengan baik, serta adanya area hijau baik di area parkir pintu utara maupun area peron yang menghambat polusi udara dan panas kendaraan.

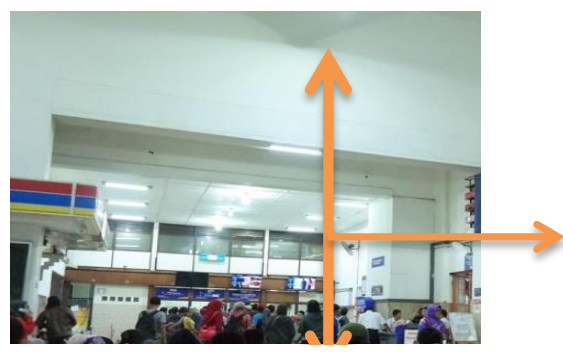

Ketinggian

langit-langit

mencapai +709

$\mathrm{cm}$.

Gambar 7. Ketinggian langit-langit Stasiun Bandung Hall Selatan Sumber: Data pribadi 2015

\subsection{Intensitas Penerangan atau Pencahayaan}

Pencahayaan ruang tunggu pada hall Selatan tidak terlalu baik. Hal ini dikarenakan pada hall selatan cahaya alami datang dari dua bagian utama yaitu cahaya dari pintu Selatan dan jendela area loket. Cahaya matahari langsung yang masuk dari pintu Selatan cenderung silau. Pada area antrian karcis, cahaya cenderung redup. Hal ini dikarenakan oleh sumber cahaya alami yang jauh dari area loket, lampu yang ditempatkan langsung pada plafon berketinggian $7 \mathrm{~m}$, jumlah lampu yang sedikit, dan penataan lampu di area antrian loket yang tidak merata. Berbagai hal tersebut menyebabkan pencahayaan pada area tunggu hall Selatan tidak baik. 


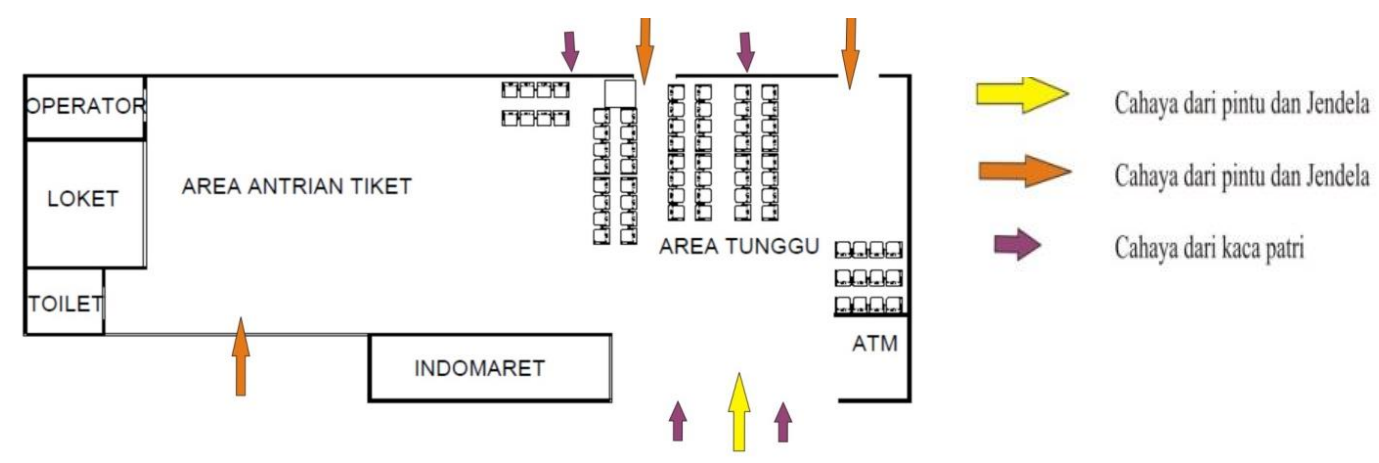

Gambar 8. Sumber datangnya cahaya Stasiun Bandung

Sumber: Data pribadi 2015.

Cahaya masuk area loket tidak maksimal karena jarak yang jauh

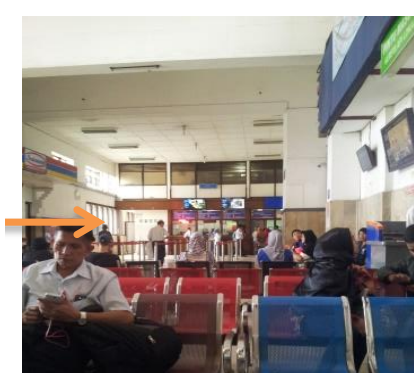

Gambar 9.Sumber cahaya ruang tunggu Stasiun Bandung Sumber: Data pribadi 2015.
Kaca patri, cahaya masuk tidak maksimal (tidak merata) cahaya tidak menyebar

Cahaya masuk dari pintu selatan g silau, ılan pada amik

Tabel 4. Analisis Penerangan Ruang Tunggu Stasiun Bandung dengan menggunakan aplikasi android Lux Meter

Sumber: Data pribadi 2016.

\begin{tabular}{|l|l|l|l|}
\hline No & Lokasi & Hasil Penerangan & Standar Penerangan \\
\hline 1 & $\begin{array}{l}\text { Area tunggu Stasiun } \\
\text { Bandung pintu selatan }\end{array}$ & 187 lux & 200-250 lux \\
\hline
\end{tabular}

Dari hasil pengukuran intensitas penerangan menggunakan aplikasi android Lux Meter, didapatkan bahwa penerangan ruang tunggu Stasiun Bandung pintu Selatan belum memenuhi standar penerangan dari pemerintah karena belum mencapai 200-250 lux. Di lapangan terlihat pada ruang tunggu menggunakan lampu TL, penerapan lampu TL dianggap paling baik untuk ruang publik karena cahaya yang merata dan panas yang dihasilkan tidak besar serta tidak menyilaukan. Hal ini sesuai dengan standar pemerintah. Akan tetapi, tinggi langit-langit pada ruang tunggu berpengaruh pada kekuatan intensitas pencahayaan karena penempatan lampu pada langit-langit tinggi akan menyebabkan turunnya intensitas cahaya ke bawah.

Pada foto di bawah ini terlihat area counter loket yang plafondnya lebih rendah, kemungkinan diturunkan dari ketinggian asal, tampak terang. Sementara itu, area antrian terlihat lebih redup karena jarak plafond yang jauh lebih tinggi daripada area counter loket. 


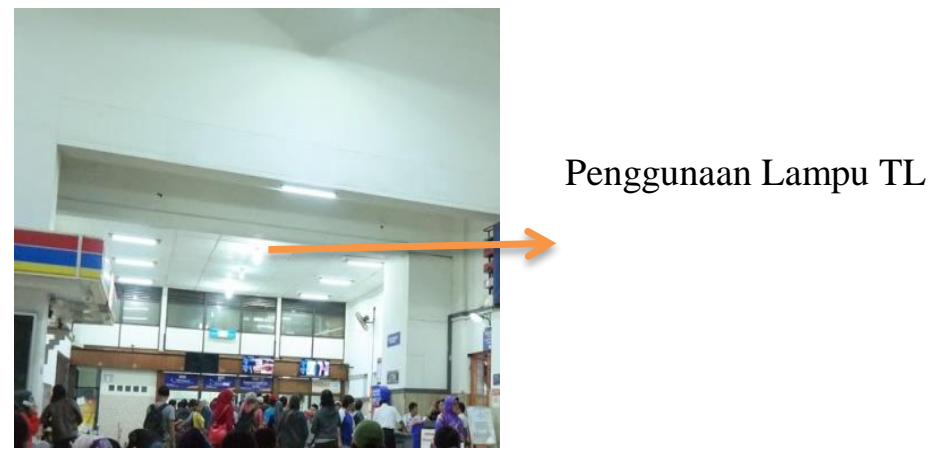

Gambar 10. Penerangan Stasiun Bandung

\subsection{Kebisingan}

Sumber :Data pribadi 2015.

Berdasarkan hasil pengukuran dari aplikasi android, diperoleh angka kebisingan normal di ruang tunggu Stasiun Selatan adalah 55dB. Angka ini dapat dikatakan wajar dan tidak mengganggu secara fisik karena batas kebisingan aman berada pada angka 85dB. Dengan demikian, kebisingan pada ruang tunggu tidak mengganggu aktivitas pengguna. Pengguna masih dapat beraktivitas dan berkomunikasi dengan baik.

Tabel 5.Pengukuran Tingkat Kebisingan Ruang Tunggu Stasiun Bandung dengan menggunakan aplikasi android Sound Sensor, Android Sensor Box, Sound Meter

\begin{tabular}{|l|l|l|l|l|}
\hline No & Aplikasi & $\begin{array}{l}\text { Hasil Pengukuran } \\
\text { Kebisingan saat } \\
\text { tidak ada kereta }\end{array}$ & $\begin{array}{l}\text { Hasil Pengukuran } \\
\text { Kebisingan Saat Kereta } \\
\text { Datang dan Pergi }\end{array}$ & $\begin{array}{l}\text { Batas Kebisingan } \\
\text { yang Aman }\end{array}$ \\
\hline 1 & Sound Sensor & $55 \mathrm{~dB}$. & $90 \mathrm{~dB}$ & $80-85 \mathrm{~dB}$ \\
\cline { 1 - 4 } & $\begin{array}{l}\text { Android Sensor } \\
\text { Box }\end{array}$ & $55 \mathrm{~dB}$. & $90 \mathrm{~dB}$ & \\
\cline { 1 - 3 } 3 & Sound Meter & $\begin{array}{l}75 \mathrm{~dB} \text { (pada hari } \\
\text { yang berbeda) }\end{array}$ & $95 \mathrm{~dB}$ & \\
\hline
\end{tabular}

Sumber: Data pribadi 2016.

Bunyi yang mengganggu dalam kasus ruang tunggu stasiun kereta api adalah bunyi kereta api itu sendiri. Berdasarkan penelitian yang dilakukan dengan menggunakan aplikasi Sound Meter, Sound Sensor, dan Android Sensor Box, kebisingan yang timbul di ruang tunggu dari kereta api yang berjalan adalah 90-95 dB. Hal ini juga dibuktikan dengan penelitian dari Tambunan (2005) dalam bukunya Occupational Noise, yang menyatakan bahwa kebisingan suara kereta api mencapai $95 \mathrm{~dB}$. Hal yang menyebabkan kebisingan di ruang tunggu masih besar adalah jarak peron dan ruang tunggu yang berjarak $5 \mathrm{~m}$.

Adapun yang mengurangi tingkat kebisingan adalah adanya tembok pada ruang tunggu. Oleh karena ambang tingkat kebisingan maksimal adalah $85 \mathrm{~dB}$, maka dapat dikatakan bahwa saat kereta api datang dan pergi suara yang ditimbulkan akan menganggu aktivitas. Akan tetapi bunyi ini tidak berdampak pada psikologi, kesehatan, dan kenyamanan pengguna ruang tunggu secara keseluruhan karena intensitas dan frekuensinya yang tidak terjadi terus menerus.

Tingkat kebisingan yang dapat mengganggu adalah dimana frekuensi bunyi terjadi terus menerus selama 50 jam dalam satu minggu. Pada keadaan normal dimana tidak ada suara kereta 


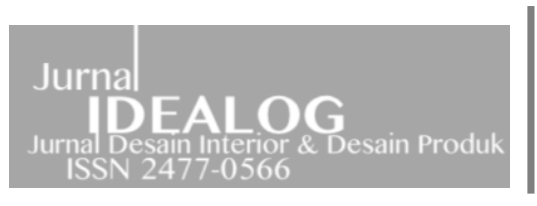

api, tingkat kebisingan pada ruang tunggu stasiun adalah $55 \mathrm{~dB}$ yang bersumber dari pengunjung yang tidak padat dan kecenderungan aktivitas yang dilakukan adalah duduk dan diam menunggu keberangkatan, sehingga tingkat kenyamanan ruang tunggu dapat terpenuhi.

\subsection{Sirkulasi Udara}

Sirkulasi udara pada area tunggu menggunakan ventilasi silang dimana udara mengalir dari luar (daerah bertekanan tinggi) menuju ke dalam ruangan (daerah bertekanan rendah) yang terjadi karena temperatur lingkungan luar lebih tinggi daripada temperatur ruang dalam. Terjadinya ventilasi silang karena ada dua bukaan berupa pintu dan jendela yang terdapat ada dua sisi dinding bangunan yang saling berhadapan.Ventilasi silang (horizontal) terjadi karena udara pada area tunggu masuk melalui pintu dan jendela pada dinding selatan dan keluar melalui pintu pada dinding utara dimana pintu dan jendela tidak langsung tegak lurus.

Dengan kondisi ini, udara pada ruang tunggu dapat mengalir di seluruh area ruang karena udara tidak langsung menuju ke area luar. Akan tetapi pada daerah merah pada gambar tidak ada lubang ventilasi apapun. Aliran udara pada ruang tunggu Stasiun Bandung Hall Selatan hanya melalui jendela dan pintu. Posisi langit-langit yang tinggi membantu agar udara panas tidak mencapai daerah aktivitas pada ruang tunggu. Ruang tunggu Stasiun Bandung Hall Selatan mengunakan kipas angin di bagian berdinding masif tanpa lubang sirkulasi sebagai sirkulasi udara buatan sesuai dengan standar Menteri Perhubungan No 48 tahun 2015. Dengan demikian, kenyamanan sirkulasi udara pada ruang tunggu Stasiun Bandung Hall Selatan dapat terpenuhi walau dengan lingkungan yang padat.
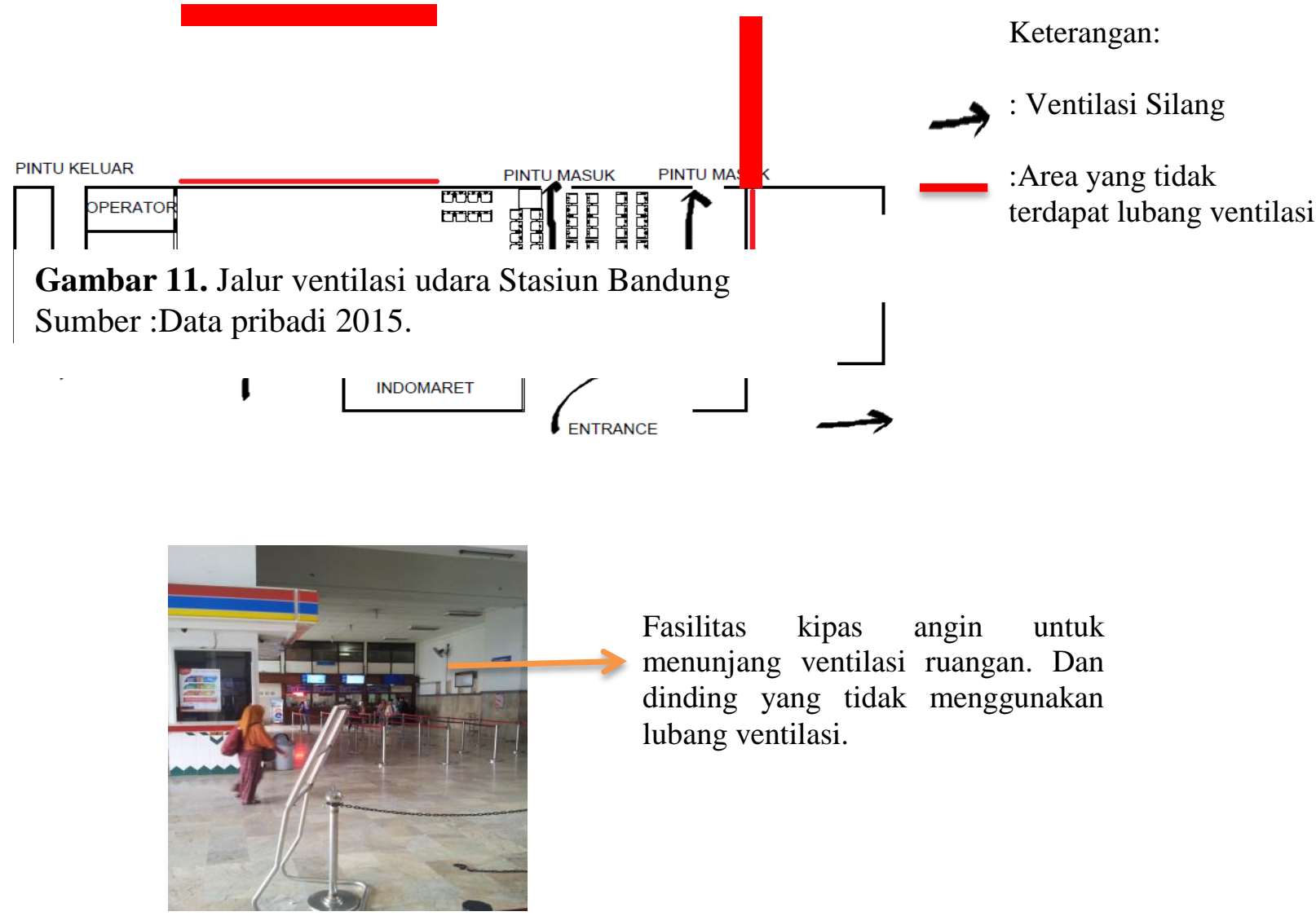

Fasilitas kipas angin untuk menunjang ventilasi ruangan. Dan dinding yang tidak menggunakan lubang ventilasi.

Gambar 12. Fasilitas ventilasi udara ruang tunggu Stasiun Bandung Sumber :Data pribadi 2015. 


\subsection{Bau-bauan dan Kelembaban}

Menurut pengamatan di lapangan, ruang tunggu stasiun terbebas dari bau-bau tidak sedap yang mengganggu. Adapun bau-bauan yang tercium berasal dari outlet-outlet makanan di sekitar ruang tunggu, tetapi bau-bauan ini masuk kategori bukan polutan. Bau sebagai polutan muncul akibat kelembaban udara. Ruang tunggu jauh dari sumber bau polutan dan hal ini berbanding lurus dengan data kelembaban yang penulis dapatkan. Berdasarkan analisis melalui aplikasi Android, diperoleh data kelembaban udara disekitar ruang tunggu adalah $60 \%$, yang merupakan angka kelembaban normal untuk level kenyamanana ruang tunggu serta tidak menimbulkan bau-bauan yang mengganggu.

Tabel 6.Data kelembaban udara ruang tunggu Stasiun Bandung.

\begin{tabular}{|l|l|l|}
\hline No & Aplikasi Android & Kelembaban \\
\hline 1 & Smart Thermometer & $60 \%$ \\
\hline 2 & Humidity Sensor (Android Sensor Box) & $60 \%$ \\
\hline
\end{tabular}

Sumber: Data pribadi 2015.

\subsection{Getaran Mekanis}

Di Stasiun Bandung Hall Selatan, satu-satunya getaran mekanis yang terasa pada ruang tunggu adalah getaran kereta api di peron yang berjarak $5 \mathrm{~m}$ dari ruang tunggu. Getaran timbul hingga ke ruang tunggu sehingga aktivitas pengguna ruang tunggu menjadi terganggu sejenak. Getaran semacam ini dapat mengganggu tubuh jika berlangsung secara terus menerus hingga dapat mengakibatkan hilang konsentrasi dan komunikasi. Akan tetapi, karena frekuensi yang tidak terus menerus, penerimaan getaran di Stasiun Bandung Hall Selatan dianggap wajar dan tidak mempengaruhi kegiatan secara keseluruhan. Sehingga dapat dikatakan bahwa kenyamanan ruang tunggu masih terjaga.

\subsection{Fasilitas}

Kursi tunggu yang digunakan adalah kursi panjang empat seat. Kondisi kursi tidak terlalu baik karena banyak yang sudah berkarat dan warna yang tidak senada. Dari segi kekuatan dan bentuk fisik, tidak terdapat perubahan bentuk signifikan maupun kerusakan fisik parah sehingga masih dapat diduduki dengan baik.
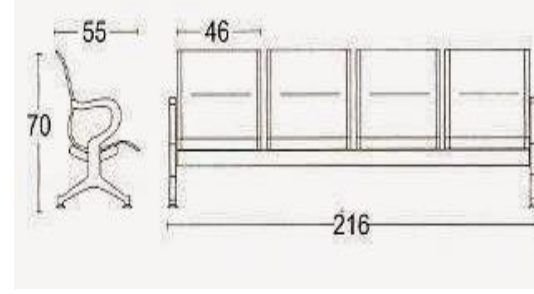

n kursi tunggu Stasiun aorto@blogspot.com

Bandung

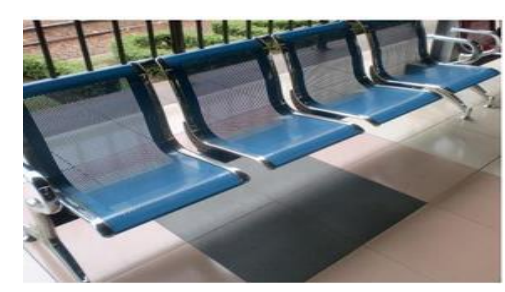

Gambar 14.Kursi tunggu Stasiun

Sumber: Data pribadi 2015. 


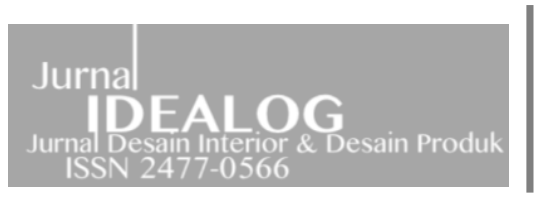

Pada ruang tunggu terdapat 52 seat. Terbagi menjadi dua area pada ujung dekat ruang kantor sebanyak 12 seat, dan sisanya pada area utama. Di area ini kursi pada posisi satu garis lurus dengan jarak baris depan dan belakang $60 \mathrm{~cm}$. Saat dilakukan observasi, kursi tunggu masih mampu menampung penggunjung. Akan tetapi, saat masa-masa tertentu kursi tidak mampu memenuhi kebutuhan pengunjung.

Penataan kursi yang kurang teratur, seperti kursi yang saling berhadapan tetapi tidak memperhatikan jarak sirkulasi, adanya kursi yang saling membelakangi tetapi langsung berhadapan dengan sirkulasi utama (sirkulasi menuju area peron), serta kursi tunggu yang berada di depan pintu kantor kepala stasiun. Fasilitas tempat duduk tidak memenuhi kebutuhan pada saat-saat tertentu, terutama saat peak time dimana kepadatan pengunjung tinggi dan jumlah penumpang yang menunggu banyak.
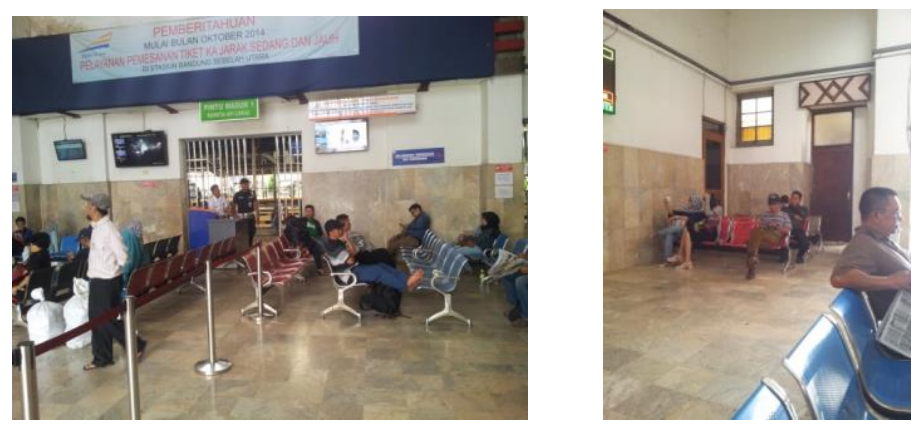

Gambar 14. Kursi tunggu Stasiun Bandung

Sumber: Data pribadi 2015

\section{Kesimpulan}

Dari hasil observasi, ditemukan bahwa dari delapan aspek kenyamanan ruang yang ditinjau dari ergonomi kenyamanan lingkungan, didapat beberapa hal yang belum memenuhi standar kenyamanan. Diantaranya sirkulasi yang belum memenuhi standar zona gerak dan kebutuhan aktivitas baik bagi pengguna normal maupun diffable, tidak adanya jarak pada area aktivitas penguna ruang tunggu dan petugas tiket. Diperlukan penataan ulang di bagian area tunggu untuk mengoptimalkan ruangan dan menyesuaikan dengan jumlah dan frekuensi kepadatan pengunjung. Ruang tunggu Stasiun Bandung Hall Selatan kurang memenuhi aspek untuk penyandang cacat, khususnya pada area sirkulasi.

Perlu dilakukan intervensi interior untuk mengatasi persoalan pencahayaan ini dengan cara mengatur plafond dan penambahan jumlah lampu dengan intensitas yang lebih tinggi. Bentuk ruangan dengan plafond tinggi dan bentukan serta luas bukaan mempengaruhi faktor pencahayaan dalam ruang. Pada ruang tunggu pencahayaan agak redup karena penataan lampu yang tidak merata. Selain itu, tingginya plafond mengakibatkan sebaran cahaya ke area bawah banyak berkurang, sehingga intensitas cahaya di area aktivitas rendah.

Pada tinjauan temperatur atau suhu ruangan, sirkulasi udara dan bau-bauan, ruang tunggu dinyatakan nyaman karena memenuhi standar kenyamanan yang ada. Sedangkan dalam hal kebisingan dan getaran mekanis pada ruang tunggu ada sumber bunyi yang melebihi batas dan mengganggu aktivitas, tetapi dianggap sesuatu yang wajar pada stasiun karena frekuensi getaran tidak berlangsung terus menerus. 


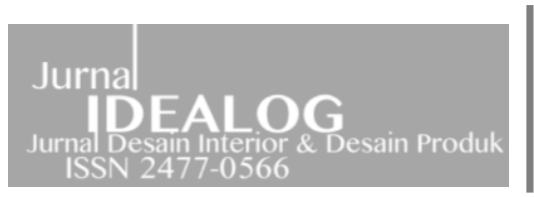

Berdasarkan hasil penelitian, diperlukan beberapa intervensi interior untuk mengoptimalkan tingkat kenyamanan ruang tunggu Stasiun Bandung Hall Selatan, diantaranya penataan ulang furnitur untuk memperbaiki sirkulasi dan menambah kapasitas tunggu, penataan pencahayaan buatan dan pengaturan ketinggian plafon untuk optimalisasi cahaya, penataan layout dengan desain universal untuk mengakomodasi pengguna diffable dan berkebutuhan khusus.

\section{Daftar Pustaka}

[1] Nurmianto, Eko. 1996. Ergonomi, konsep Dasar dan Aplikasinya. PT. Guna Widya, Jakarta

[2] Yudiawan, Deni (Ed). 2016. Ngalingkung Bandung: Exploring Bandung. Granesia Pikiran Rakyat, Bandung

[3] Laela. 2015. Fisika Bangunan. Griya Kreasi, Jakarta

[4] Suma'mur, PK. 1996. Higiene Perusahaan Kesehatan dan Kenyamanan Kerja. CV Haji Massagung, Jakarta

[5] Hakim, Abdul. 2006. Analisis Pengaruh Motivasi Dan Iklim Terhadap Kinerja Pegawai Pada Dinas Perhubungan Dan Telekomunikasi Provinsi Jawa Tengah. JRBI. Vol 2. No2. Hal 165-180

[6] Santosa Anto. 2006. Pencahayaan Pada Interior Ruang Tunggu: Studi Kasus Ruang Tunggu Stasiun Kereta Api Yogyakarta. Skripsi tidak dipublikasikan

[7] Talarosha, Basari. 2005. Menciptakan Kenyamanaan Termal Dalam Bangunan, Jurnal Sistem Teknik Industri, Vol. 6, No 3

[8] Tambunan, Sihar Tigor Benjamin. 2005. Kebisingan di tempat kerja (Occupational Noise). Penerbit Andi, Yogyakarta

[9] Peraturan Menteri Perhubungan Nomor 48 Tahun 2015 Tentang Standar Pelayanan Minimum Untuk Angkutan Orang Dengan Kereta Api

[10] Peraturan Menteri Kesehatan Nomor 15/05 tahun 2002 tentang Lingkungan Kerja

[11] Keputusan Menteri Lingkungan Hidup Nomor 48 Tahun 1996 tentang Tingkat Baku Kebisingan

[12] Anonim. 2014. Ganesaorto. (Gambar). Diakses www.ganesaorto@blogspot.com. (23 Oktober 2015)

[13] https://komunitasaleut.com/2011/09/28/sejarah-stasiun-kereta-api-bandung/ Desember 2016)

[14] http://www.stasiunbandung.com/stasiun-bandung/ (23 Desember 2016) 
